\title{
MOTIVATIONS, INTENTIONS TO RETURN AND TO RECOMMEND PROTECTED AREAS: A STUDY IN COSTA RICA
}

\author{
Mauricio CARVACHE-FRANCO \\ Espíritu Santo University-Ecuador, Av. Samborondón, \\ Samborondón 092301, Ecuador, e-mail: mauricio2714@hotmail.com \\ Ana Gabriela VÍQUEZ-PANIAGUA \\ Costa Rica Institute of Technology, Business Administration Career, Campus San Carlos, \\ P.O. Box 159-7050, Alajuela, Costa Rica, e-mail: aviquez@itcr.ac.cr

\section{Orly CARVACHE-FRANCO} \\ Catholic University of Santiago de Guayaquil, Faculty of Business Specialties, \\ Av. Carlos Julio Arosemena Km 1.5, Guayaquil, Ecuador, e-mail: orly.carvache@cu.ucsg.edu.ec

\begin{abstract}
Allan PEREZ-OROZCO
Costa Rica Institute of Technology, Business Administration Career, Campus San Carlos, P.O. Box 159-7050, Alajuela, Costa Rica, e-mail: aperez@itcr.ac.cr
\end{abstract}

\section{Wilmer CARVACHE-FRANCO*} \\ ESPOL Polytechnic University, Escuela Superior Politécnica del Litoral, ESPOL, \\ Faculty of Social Sciences and Humanities, Campus Gustavo Galindo Km 30.5 Vía Perimetral, \\ P.O. Box 09-01-5863, Guayaquil, Ecuador, e-mail: wcarvach@espol.edu.ec
}

\begin{abstract}
Citation: Carvache-Franco, M., Víquez-Paniagua, A.G, Carvache-Franco, O., Perez-Orozco A., \& Carvache-Franco W. (2019). MOTIVATIONS, INTENTIONS TO RETURN AND TO RECOMMEND PROTECTED AREAS: A STUDY IN COSTA RICA. GeoJournal of Tourism and Geosites, 27(4), 1173-1183. https://doi.org/10.30892/gtg.27405-424
\end{abstract}

\begin{abstract}
In recent years, there has been a growing interest among tourists for the enjoyment of the natural environment. This study was designed to analyze the motivations tourists exhibit to doing ecotourism and their influence on the intentions to return and recommend a protected area. The empirical analysis was carried out in the Arenal National Park and the Caño Negro National Wildlife Refuge in Costa Rica. The sample population consisted of 213 respondents, who were obtained in situ. A factor analysis and the multiple regression method were performed to analyze the data obtained. The results show that there are several motivational dimensions related to ecotourism, such as "self-development", "interpersonal relationships and ego-defensive function", "nature", "building personal relationships", "reward" and "escape". There is a relationship between the motivations and the intentions of returning and recommending the site. This research will serve public institutions and private companies to develop more efficient marketing plans.
\end{abstract}

Keywords: motivation, satisfaction, recommendation, return, ecotourism

\footnotetext{
${ }^{*}$ Corresponding author
} 


\section{INTRODUCTION}

Ecotourism has an annual growth of $5 \%$ worldwide, and it grows three times faster than tourism in general (Hultman et al., 2015). Its importance increases because it has become one of the fastest-growing sectors in the tourism industry (Das \& Chatterjee, 2015). The tourism influences the socio-cultural, economic, and environmental livelihood of the community (Atanga, 2019). Tourists seek meaningful experiences, such as getting in touch with local communities, learning about an ecosystem, and participating in the conservation of natural resources (Balmford et al., 2009). Ecotourism areas have become crucial destinations due to their efficiency in environmental protection, education, recreation, and job creation (Tao \& Wall, 2009). At the same time, tourists are more environmentally aware and have stronger motivations to attend attractions and activities due to environmentally-related content (Luo \& Deng, 2008). Motivation has become a fundamental concept in traveling behavior analysis, and it determines different aspects of tourism, in regards to the reasons for traveling, the specific destination and general satisfaction with the trip (Castaño et al., 2003). In this sense, each visitor can have different motivations and preferences for different destinations (Kozak, 2002).

On the other hand, attracting new visitors is more expensive than attracting those who have already visited the destination (Shoemaker \& Lewis, 1999). So, it is essential to analyze the motivations tourists have and their influence on their intentions to return and recommend a tourist site. However, several studies analyze these variables in ecotourism.

Costa Rica is a Central American country where visitors seek experiences, mainly, in the field of ecotourism. The Arenal National Park and the Caño Negro National Wildlife Refuge are two examples of such type of visiting areas. The Arenal National Park houses the Arenal Volcano, an icon of Costa Rican nature which began its activity in 1968, after 500 years of being in a dormant status. This protected area is a living laboratory, because of its geological and geomorphological richness and its complexity in the development of biological processes, as it houses a wide range of greenery, from pioneer vegetation to primary forests. The Caño Negro National Wildlife Refuge is a wetland concentrating a large number of endangered species. Visitors can find migratory birds, many mammals, and some endemic freshwater fish. There are also swamps and lagoons throughout the reserve. This article presents an analysis of the motivations to do ecotourism and their influence on the intentions to recommend and return to the Arenal National Park and the Caño Negro National Wildlife Refuge. Thus, providing information to tourism marketers which will help them plan efficient marketing strategies. To meet this objective, this article is organized in several sections, beginning with the introduction, followed by the second section where the relevant literature is reviewed, the third section describes the area of study, while the fourth one looks at the research methodology, the following section covers the results, to end up with the discussion of results, the conclusions reached, as well as the limitations of the study and what it is believed to be possible future lines of research.

\section{THEORETICAL FRAMEWORK}

\section{Motivations in ecotourism}

Motivation is defined as the psychological needs and desires that provoke, direct, and integrate behavior and activity (Pearce, 2013). Also, motivational factors are defined as psychological needs that play an important role in making a person feel a psychological imbalance that can be corrected through a traveling experience (Crompton, 1979; Kim et al., 2000). Furthermore, Meng et al. (2008), explain that motivations are the set of needs which influence a person to participate in a tourist activity. It is the central factor in the decision-making process (Yolal et al., 2015). The study of motivations allows us to 
understand the choice, preferences, and needs of a traveler (Bansal \& Eiselt, 2004). Also several authors ascertain that motivation determines the intention to visit the destination and some of them establish a relationship between satisfaction and the intention to return to the destination (Huang \& Hsu, 2009; Jang \& Feng, 2007; Rittichainuwat et al., 2008; Yoon \& Uysal, 2005; Lee et al., 2014). In addition, Yoon and Uysal (2005) mention that it is essential to understand the motivations of tourists and their relationship during the visit. Tourists have different reasons to visit different attractions and destinations which are related to nature (Chikuta et al., 2017). Relaxation in a natural environment was described as an essential need for ecotourists.

In ecotourism, several motivations drive tourists to a coastal national park (Carvache-Franco et al., 2019a). In this sense, Holden and Sparrowhawk (2002) point out that the main intrinsic motivations for ecotourists are to learn about nature, be physically active, and meet people with a similar interest. Page and Dowling (2002) mention that some ecotourists travel to meet their recreational and pleasure needs, as well as to learn about specific areas. Lee et al. (2014) analyzed tourists visiting restored ecological parks in South Korea, finding seven factors related to their motivations. Namely, they identified self-development, interpersonal relationships, rewards, development of personal relationships, escape, ego-defensive function, and appreciation of nature as the primary motivations. Going further, Panin and Mbrica (2014), found in the Republic of Serbia the most important motivations for ecotourists, to be social activities, sports and health activities, motivation for nature and culture and educational activities. They argue that the motivations related to sports and recreational activities, the positive impact on health, walking through the forest, seeing and enjoying nature, are the main motivations in ecotourism. Regarding the characteristics of ecotourists, Cheng, Gurzoy, and Del Chiappa (2016) consider that ecotourists would positively influence the intention, interest, and willingness to pay a higher price for ecotourism products and services. In this sense, Nickerson, Jorgenson, and Boley (2016) have concluded that sustainable tourists are willing to spend more money, which can increase the income of sustainable tourism destinations.

\section{STUDY AREA}

The Arenal National Park is located in the North Region of Costa Rica, in the Guanacaste Volcanic Mountain Range, north of the Sierra de Tilarán and part of the San Carlos plains. It has an extension of 12,124 hectares. The land's surface is irregular, from deep valleys with significant slopes, cut by large rivers, to flat and undulating forms. It is considered an aquifer recharge area, whose waters drain to the Arenal Reservoir for their use in the production of hydroelectric power and agricultural projects, like in the Irrigation District of Moracia. The Chiquito, Peñas Blancas, and Río Frío rivers are born here. The Park protects essential species of flora and fauna which are characteristic of the premontane rain forest and the cloud forest and of great scientific and tourist value. Among the most outstanding wildlife species we have: pacas, tapirs, deer, jaguars, peccaries, white-nosed coatis, and monkeys. A great diversity of snakes, as well as birds of various varieties among which stand out: praises, sergeants, brown magpies, parakeets, hummingbirds, bell birds, among others. The Caño Negro National Wildlife Refuge is located in the lower part of the Frío river basin, in the Northern Plains, $21 \mathrm{~km}$ south-west of the community of Los Chiles and $36 \mathrm{~km}$ southeast of the community of Upala, in the cantons of the same name in the province of Alajuela. Visitors have to go through the reservation by canoe or boat, depending on the weather conditions, and it has an area of 10,171 hectares. The refuge conserves one of the most important samples of humid areas of the Costa Rican territory, considered of international importance for serving as a large number of migratory, endangered and environmentally important species (Figure 1). 


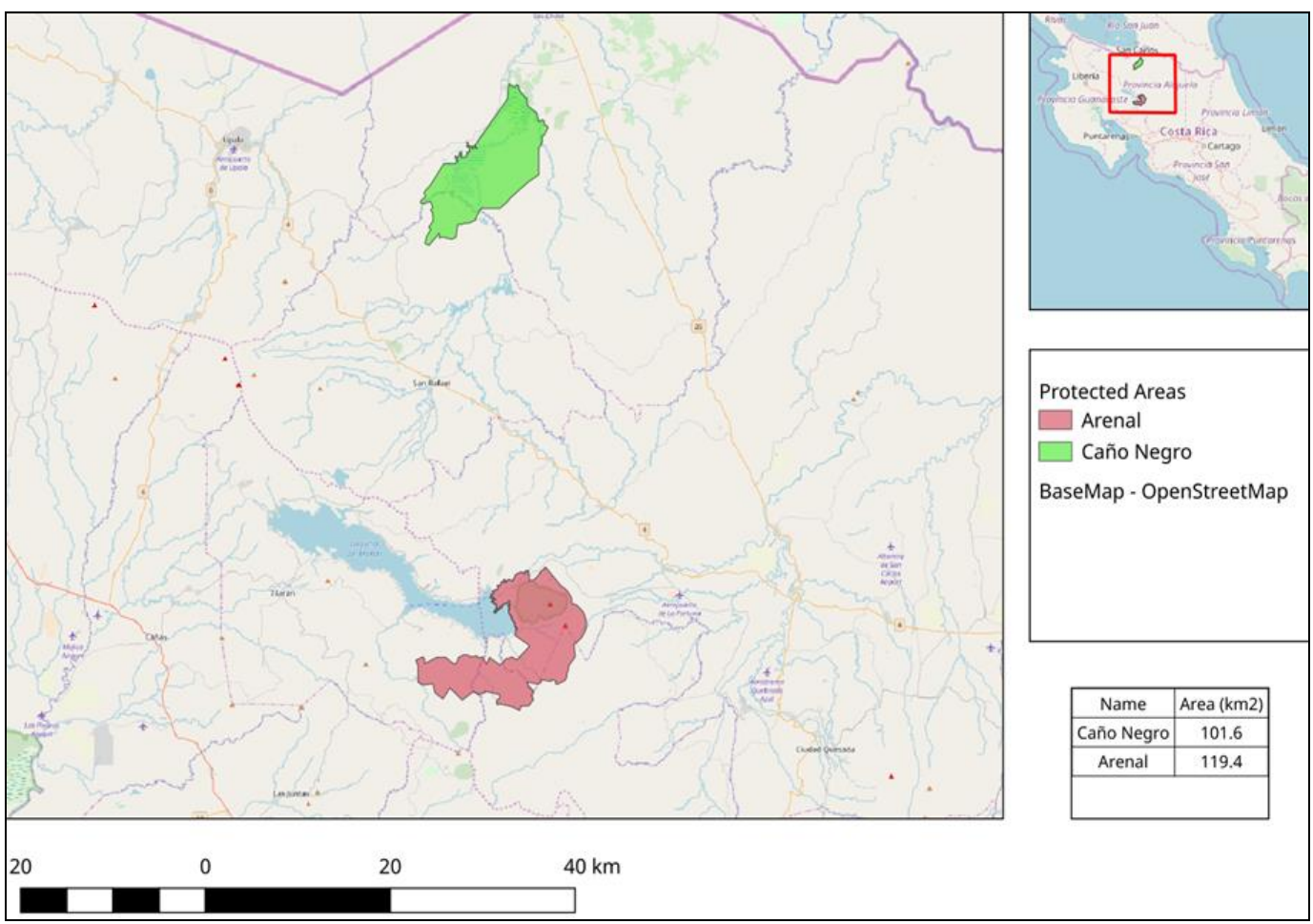

Figure 1. Geographic location of protected areas:

Arenal Volcano National Park and Caño Negro Mixed National Wildlife Refuge (Costa Rica)

\section{METHODOLOGY}

The sample population was obtained from national and foreign tourists who were, at the time of doing the study, visiting the Arenal National Park with 106,461 visitors in 2017 (Costarrican Institute of Tourism, 2017) and the Caño Negro National Wildlife Refuge. Surveys were applied, during March and April of the year 2019, to visitors of the aforementioned protected areas. The measurement tools developed for this study were based on several previous studies on motivations in tourism (Crompton, 1979; Fodness, 1994; Weaver \& Lawton, 2002; Galley \& Clifton, 2004; Lau \& McKercher, 2004; McGehee \& Kim, 2004; Jang \& Wu, 2006; Lee et al., 2014). Using the SPSS Statistical System, the Cronbach Alpha index reached the value of 0.94 , indicating a meritorious index on the scale. The questionnaire for this study was divided into two parts. The first part of the questionnaire measured the sociodemographic and visiting characteristics of the respondents. The second part of the questionnaire consisted of questions based on a fivepoint Likert scale, where 1 was little and 5 a lot. This section measured the motivations, satisfaction, and intentions of returning and recommending the site.

The data were analyzed in two stages. First, a factor analysis, which has been widely used in visitor segmentation research (Formica \& Uysal, 1998; Kastenholz et al., 1999; Johns \& Gyimothy, 2002), was carried out which helped identify the constructs that underlie the variables, providing a global view of the most important motivations using those constructs. Varimax rotation was used to facilitate the interpretation of the data. The Kaiser criterion was used to find the number of factors, where only factors with eigenvalues greater than one were used. The KMO index (Kaiser-Meyer-Olkin) and 
Bartlett's Sphericity test were used to determine if it was appropriate perform the factor analysis. In the second stage, the step-by-step multiple regression method was implemented to assess the intentions of returning and recommending the ecotourism destinations. The population variability was estimated at $50 \%(\mathrm{p}=\mathrm{q}=0.5)$. The sample size, considering a margin of error of $+/-6.7 \%$ and a confidence level of $95 \%$, came out at 213, which was the number of surveys applied. The data collected was organized, tabulated, and statistically analyzed using the SPSS 22.0 program.

Table 1. Sociodemographic characteristics of the visitors

\begin{tabular}{|c|c|c|c|}
\hline Demographics & Categories & $\mathbf{n}$ & Percentage \\
\hline \multirow{2}{*}{ Nationality } & National & 57 & 26.8 \\
\hline & Foreign & 156 & 73.2 \\
\hline \multirow{5}{*}{ Origin } & North America & 46 & 21.6 \\
\hline & \begin{tabular}{|l|} 
Europe \\
\end{tabular} & 90 & 42.3 \\
\hline & South America & 7 & $3 \cdot 3$ \\
\hline & Asia & 8 & 3.8 \\
\hline & Rest of the world & 62 & 29.1 \\
\hline \multirow{2}{*}{ Gender } & Male & 102 & 47.9 \\
\hline & Female & 111 & 52.1 \\
\hline \multirow{6}{*}{ Age } & $<20$ years of age & 17 & 8.0 \\
\hline & $21-30$ years of age & 86 & 40.4 \\
\hline & $31-40$ years of age & 38 & 17.8 \\
\hline & $41-50$ years of age & 32 & 15.0 \\
\hline & $51-60$ years of age & 32 & 15.0 \\
\hline & $>60$ years of age & 8 & 3.8 \\
\hline \multirow{3}{*}{ Marital status } & Single & 97 & 45.5 \\
\hline & Married & 86 & 40.4 \\
\hline & Other & 30 & 14.1 \\
\hline \multirow{4}{*}{ Level of education } & \begin{tabular}{|l|} 
Primary \\
\end{tabular} & 9 & 4.2 \\
\hline & Secondary & 37 & 17.4 \\
\hline & University & 102 & 47.9 \\
\hline & Postgraduate (Master/PhD.) & 65 & 30.0 \\
\hline \multirow{8}{*}{ Professional activity } & Student & 32 & 15.0 \\
\hline & Researcher / scientist & 5 & 2.3 \\
\hline & Businessperson & 38 & 17.8 \\
\hline & Private Employee & 58 & 27.2 \\
\hline & Public Employee & 40 & 18.8 \\
\hline & Retired & 7 & 3.3 \\
\hline & Unemployed & 6 & 2.8 \\
\hline & Other & 26 & 12.2 \\
\hline \multirow{5}{*}{ Who you visit with } & Alone & 8 & 3.8 \\
\hline & With family & 77 & 36.2 \\
\hline & With friends & 57 & 26.8 \\
\hline & With a partner & 64 & 30.0 \\
\hline & Other & 7 & $3 \cdot 3$ \\
\hline \multirow{6}{*}{ Average daily expenditure } & $<\$ 30$ & 37 & 17.4 \\
\hline & $\$ 30.01-\$ 60$ & 71 & 33.3 \\
\hline & $60.01-\$ 90$ & 44 & 20.7 \\
\hline & $\$ 90.01-\$ 120$ & 27 & 12.7 \\
\hline & $\$ 120.01-\$ 150$ & 20 & 9.4 \\
\hline & $\$ 150$ & 14 & 6.6 \\
\hline
\end{tabular}




\section{RESULTS}

The sociodemographic and visiting traits of the respondents are presented in Table 1. From the total number of respondents, $26.8 \%$ of them were national visitors, while $73.2 \%$ of the sample were foreign tourists. When asked about their countries of origin, 42.3\% disclosed coming from European countries. Whilst, $47.9 \%$ of visitors were men and the remaining $52.1 \%$ disclosed their sex to be, female. $44.5 \%$ of the travelers surveyed reported to be single and $40.4 \%$ were married. The majority of the vacationers consulted ranged the age of $21-30(40.4 \%)$ and the $31-40$ age range came to $17.8 \%$. They acknowledged having a university education, $47.9 \%$ of them, while $30.0 \%$ had postgraduate education. Regarding occupation, 27.2\% were private employees and $18.8 \%$ were public employees. At the moment of asking for the average amount of money they spent at the destination, 20.7\% replied that it had been between 60 to 90 dollars a day. Finally, approximately $36.2 \%$ of the visitors traveled to the destination accompanied by other family members and $26.8 \%$ were enjoying the destination with their friends.

\section{Factorial analysis}

A factor analysis was carried out, allowing the extraction of six motivational dimensions. The principal component analysis was adopted as a technique performed for data reduction. The Varimax rotation method was applied to obtain a more precise interpretation of the factors so that each one had very high or low factor loads. For the number of factors used in the Kaiser criteria, factors having their eigenvalues greater than 1.00 were taken into account. Six factors were part of the solution and represented $69.85 \%$ of the total variance. The KMO index (Kaiser-Meyer-Olkin) is 0.91 , so it is excellent for factor analysis. In addition, Barlett's sphericity test is significant <0.05, so a factor analysis should be applied. Results are shown in Table 2.

According to the results presented on Table 2, the first factor identified was called "self-development" and is the factor with the greatest explanatory capacity (36.01\%) of the total variance. This first dimension was related to the motivations knowing what I am capable of, having a sense of self-confidence, getting a new perspective on life, feeling harmony and inner peace, being independent, understanding more about myself, thinking about the good times I've had in the past, and have the opportunity to know myself better. The second factor was entitled "Interpersonal relationships and ego-defensive function" which met $\mathbf{1 4 . 2 7 \%}$ of the total variance.

This second dimension was related to, remembering the times of parents, contacting family and friends who live in other places, strengthen the relationship with my family, reflecting on memories of the past, feeling that I belong, following current events and joining the social discussion. The third factor was called "nature" and comprises $6.06 \%$ of the total variance. This third dimension was related to visitors motivated by observing flora and fauna, being close to nature, observing landscapes and learning about nature. The fourth factor was called "Building personal relationships" and includes $5.06 \%$ of the total variance.

This fourth dimension is related to visitors motivated to meet new people, meeting people with similar interests, meeting locals and being with others if I need it. The fifth factor is called "Rewards" and comprises $4.72 \%$ of the total variance. This fifth dimension is related to visitors motivated to obtain good memories, explore the unknown, develop my personal interests, experience new things and have fun. The sixth factor was called "escape" and comprises $3.72 \%$ of the total variance. This sixth dimension is related to visitors motivated to be away from daily stress, to escape from routine, to avoid interpersonal stress and to be away from crowds. These results are similar to those of (Lee et al., 2014) that obtained seven motivating factors in their 
study, namely self -development, interpersonal relationships, rewards, development of personal relationships, escape, defensive ego function, and appreciation of nature.

Table 2. Factorial analysis

\begin{tabular}{|c|c|c|c|c|c|c|c|}
\hline \multirow{2}{*}{ Variables } & \multicolumn{6}{|c|}{ Componen } & \multirow{2}{*}{\begin{tabular}{|c|} 
Factors \\
\end{tabular}} \\
\hline & $\mathbf{1}$ & 2 & 3 & 4 & 5 & 6 & \\
\hline To know what I am capable of & 0.786 & & & & & & \multirow{8}{*}{$\begin{array}{l}\text { Self- } \\
\text { development }\end{array}$} \\
\hline To gain a sense of self-confidence & 0.782 & & & & & & \\
\hline \multicolumn{7}{|l|}{ To think about the good times, I have had in the past 0.724} & \\
\hline To feel inner harmony/peace & 0.717 & & & & & & \\
\hline To understand more about myself & 0.705 & & & & & & \\
\hline To be independent & 0.686 & & & & & & \\
\hline To gain a new perspective on life & 0.674 & & & & & & \\
\hline To have a chance to get to know me better & 0.66 & & & & & & \\
\hline To reminisce about parents' times & & 0.805 & & & & & \multirow{8}{*}{$\begin{array}{l}\text { Interpersonal } \\
\text { relationships } \\
\text { and ego - } \\
\text { defensive } \\
\text { function }\end{array}$} \\
\hline To contact with family/friends who live elsewhere & & 0.784 & & & & & \\
\hline To feel that I belong & & 0.743 & & & & & \\
\hline To strengthen the relationship with my family & & 0.742 & & & & & \\
\hline To reflect on memories & & 0.726 & & & & & \\
\hline To follow current events & & 0.678 & & & & & \\
\hline To join the social discussion & & 0.673 & & & & & \\
\hline To join people's interest & & 0.548 & & & & & \\
\hline For observation of flora and fauna & & & 0.79 & & & & \multirow{6}{*}{ Nature } \\
\hline To be close to nature & & & 0.774 & & & & \\
\hline For the appeal of nature & & & 0.767 & & & & \\
\hline To attain a better appreciation of nature & & & 0.748 & & & & \\
\hline To observe its landscapes & & & 0.721 & & & & \\
\hline To learn about nature & & & 0.717 & & & & \\
\hline To meet new people & & & & 0.799 & & & \multirow{4}{*}{$\begin{array}{l}\text { Building } \\
\text { personal } \\
\text { relationships }\end{array}$} \\
\hline To meet people with similar interests & & & & 0.787 & & & \\
\hline To meet the locals & & & & 0.754 & & & \\
\hline To be with others if I need them & & & & 0.687 & & & \\
\hline To have fond memories & & & & & 0.78 & & \multirow{5}{*}{ Rewards } \\
\hline To have fun & & & & & 0.739 & & \\
\hline To explore the unknown & & & & & 0.719 & & \\
\hline To develop my interests & & & & & 0.716 & & \\
\hline To experience new things & & & & & 0.655 & & \\
\hline To be away from daily stress & & & & & & 0.826 & \multirow{3}{*}{ Escape } \\
\hline To escape from routine & & & & & & 0.819 & \\
\hline To be away from the crowds of people & & & & & & 0.651 & \\
\hline Auto values & 12.24 & 4.85 & 2.06 & 1.72 & 1.61 & 1.27 & \\
\hline$\%$ of variance explained & 36.01 & 14.27 & 6.06 & 5.06 & 4.72 & 3.72 & \\
\hline KMO & \multicolumn{6}{|c|}{0.91} & \\
\hline Bartlett's sphericity test & \multicolumn{6}{|c|}{ Chi squared $=5370.498 \mathrm{sig}=0.000$} & \\
\hline
\end{tabular}

\section{The motivations and intentions to revisit these protected areas}

The step-by-step multiple regression method was used to analyze the motivational dimensions that influence tourists to re-visit protected areas. The results are shown in Table 3. Among the three functions of significant motivation (Table 3), it was found that the nature dimension was the most significant predictor of respondents' intentions to revisit the protected area $($ Beta $=0.208, \mathrm{p}<0.01)$. This means that people 
could believe that their motivations to visit the protected area kept them committed to nature. This finding is in line with the results of the research carried out by Kang et al., (2012), who studied the behavior of Ollegil's eco-tourists and found that $33.8 \%$ of the study participants had visited the site to appreciate nature. The second most significant element was the "rewards" (Beta $=0.193, \mathrm{p}<0.01)$. While the third element was "selfdevelopment" (Beta $=0.180, \mathrm{p}<0.01)$.

Table 3. Motivations and intentions to return (Multiple regression method)

\begin{tabular}{|l|c|c|c|}
\hline Motivational dimensions & Beta & $\mathrm{t}$ & Sig. \\
\hline Nature & 0.208 & 3.180 & .002 \\
\hline Rewards & 0.193 & 2.946 & .004 \\
\hline Self-development & 0.180 & 2.750 & .006 \\
\hline (Constant) & & 45.248 & .000 \\
\hline
\end{tabular}

The motivations and intentions to recommend protected areas

The step-by-step multiple regression method was used to analyze the motivational dimensions that influence tourists to recommend protected areas. The results are shown in Table 4. Among the five significant motivational functions (Table 4), it was found that the nature dimension was the most significant predictor of the intentions to recommend the protected area $(\mathrm{Beta}=0.329, \mathrm{p}<0.01)$. Meaning that people could believe that their intentions to recommend the protected area kept them committed to nature. The second most significant element was the "rewards" (Beta $=0.317, \mathrm{p}<0.01$ ). While the third most significant element was the "escape" (Beta $=0.159, \mathrm{p}<0.01)$.

Table 4. Motivations and intentions to recommend protected areas (Multiple regression method)

\begin{tabular}{|l|c|c|c|}
\hline \multicolumn{1}{|c|}{ Motivational dimensions } & Beta & t & Sig. \\
\hline Nature & 0.329 & 5.536 & 0.000 \\
\hline Rewards & 0.317 & 5.334 & 0.000 \\
\hline Escape & 0.159 & 2.679 & 0.008 \\
\hline Building personal relationships & 0.136 & 2.283 & 0.023 \\
\hline Interpersonal relationships and ego-defensive function & 0.131 & 2.205 & 0.029 \\
\hline (Constant) & & 73.909 & 0.000 \\
\hline
\end{tabular}

\section{Satisfaction at the destination}

To analyze the satisfaction attained at the destination, a 5-point Likert scale was used, where 1 was strongly dissatisfied and 5 was strongly satisfied (Table 5). According to table $5,51.2 \%$ of tourists were completely satisfied with their visit at the destination, so the potential of the destination for ecotourism is confirmed. Also, the average level of tourist satisfaction was 4.35 , being a high level of satisfaction.

Table 5. Satisfaction at the destination

\begin{tabular}{|c|c|c|c|c|c|}
\hline Variable & $\begin{array}{c}\text { Completely } \\
\text { dissatisfied }\end{array}$ & Dissatisfied & $\begin{array}{c}\text { Neither dissatisfied } \\
\text { nor satisfied }\end{array}$ & Satisfied & $\begin{array}{c}\text { Completely } \\
\text { satisfied }\end{array}$ \\
\hline Satisfaction (percentage) & $1.4 \%$ & $2.3 \%$ & $7.5 \%$ & $37.6 \%$ & $51.2 \%$ \\
\hline Satisfaction (average) & \multicolumn{5}{|c|}{4.35} \\
\hline
\end{tabular}

\section{Satisfaction and intentions to return and recommend}

To analyze the relationship between satisfaction and the intentions of returning and recommend the destination the Spearman Coefficient was used (Table 6). According to table 6, there was a significant and positive correlation between the intentions of 
returning and recommending the destination, and the satisfaction, so the intentions of returning and recommending the ecotourism destination were influenced by the satisfaction experienced by tourists.

Table 6. Intentions to return, recommend and satisfaction (Spearman's coefficient)

\begin{tabular}{|l|c|}
\hline \multicolumn{1}{|c|}{ Variables } & Coefficient \\
\hline Intentions to return to this ecotourism destination & $0.582^{* *}$ \\
\hline Intentions to recommend this ecotourism destination & $0.770^{* *}$ \\
\hline
\end{tabular}

** The correlation is significant at the o.o1 level

\section{DISCUSSION AND CONCLUSIONS}

After the study, it was concluded that the gender, age, and education of ecotourists in this study are consistent with eco-tourists from previous studies (Galley \& Clifton, 2004; Juric et al., 2002; Kwan et al., 2008; Weaver \& Lawton, 2002). In ecotourism, there are several motivational dimensions. The leading motivational dimension is "selfdevelopment," which is related to gaining self-confidence and being independent. Selfdevelopment has also been understood and defined as the search for personal growth and the desire to learn and interact with a host culture and its community (Crompton, 1979; Calantone \& Johar, 1984; Dann, 1981; Etzel \& Woodside, 1982; Woodside \& Jacobs, 1985). The second dimension is "Interpersonal relationships and defensive ego function", related to visitors motivated by the strengthening of relations with family members and the monitoring of current events. The third dimension is "nature", related to a visitor's motivation to appreciate nature. It has often been found that appreciation of the natural environment is the predominant motivation of ecotourists (Weaver \& Lawton, 2002; Wurzinger \& Johansson, 2006). The fourth dimension is "Building personal relationships", related to a visitor motivated to meet new people. People tend to behave according to socially desired issues (McGehee \& Kim, 2004). The fifth dimension is "Rewards", which relates to a visitor motivated by having fun and experiencing new things. Therefore, tourists travel to reward themselves when taking a break (Broad \& Jenkins, 2008). The sixth dimension is "Escape", related to a visitor motivated by escaping from their daily routine (Crompton, 1979; Lounsbury \& Hoopes, 1985; Woodside \& Jacobs, 1985). These findings are similar to those of (Lee et al., 2014), who found seven motivational dimensions in ecotourism (self-development, interpersonal relationships, rewards, development of personal relationships, escape, ego-defensive function, and appreciation of nature as the primary motivations. In addition, the findings above support other previous research related to the dimensions which motivate ecotourists (McGehee \& Kim, 2004; Weaver \& Lawton, 2002; Zeppel, 2008; Carvache-Franco et al., 2019b).

Also, the nature dimension is the most significant predictor of the respondents' intentions to revisit the protected area; this finding is in line with the results obtained by Kang et al. (2012). Furthermore, rewarding and self-development are also significant predictors of the intention to revisit the protected area. While, the nature dimension was the most significant predictor of intentions to recommend the protected area, followed by reward and escape. The satisfaction tourists had experienced at the destination influence their intentions of returning and recommending the destination. Therefore, if satisfaction is improved at the destination, the intentions of returning and recommending ecotourism destinations would be increased. It is recommended that the service be improved in companies and institutions that interact with tourists, in addition to improving the service in natural parks and protected areas related to ecotourism. Among the practical implications, it is worth mentioning that operators and companies linked to the tourism sector can plan strategies according to the motivations in ecotourism and thus increase 


\section{Mauricio CARVACHE-FRANCO, Ana Gabriela VÍQUEZ-PANIAGUA, Orly CARVACHE-FRANCO, Allan PEREZ-OROZCO, Wilmer CARVACHE-FRANCO}

the tourists' intentions to visit and recommend these protected areas. Finally, among the limitations, the temporality with which the study was carried out can be mentioned. In regards to the future research lines, investigation the segmentation of demand in ecotourism, using motivations as a segmentation criterion, is proposed.

\section{REFERENCES}

Atanga, R. A. (2019). Stakeholder views on sustainable community-based ecotourism: a case of the Paga crocodile ponds in Ghana. GeoJournal of Tourism and Geosites, 25 (2), 321-333. https://doi.org/ 10.30892/gtg.25204-362.

Balmford, A., Beresford, J., Green, J., Naidoo, R., Walpole, M., \& Manica, A. (2009). A global perspective on trends in nature-based tourism. PLoS Biology, 7 (6), e1000144. https://doi.org/10.1371/journal.pbio.1000144.

Bansal, H., \& Eiselt, H.A. (2004). Exploratory research of tourist motivations and planning. Tourism Management, 25(3), 387-396. https://doi.org/10.1016/So261-5177(03)oo135-3.

Broad, S., \& Jenkins, J. (2008). Gibbons in their midst? Conservation volunteers' motivations at the Gibbon Rehabilitation Project, Phuket, Thailand. Journeys of discovery in volunteer tourism: International case study perspectives, $72-85$.

Calantone, R. J., \& Johar, J. S. (1984). Seasonal segmentation of the tourism market using a benefit segmentation framework. Journal of Travel Research, 23(2), 14-24. https://doi.org/10.1177\%2Fo04728758402300203.

Carvache-Franco, M., Segarra-Oña, M., \& Carrascosa-López, C. (2019a). Segmentation and motivations in ecotourism: The case of a coastal national park. Ocean \& Coastal Management, 178, 104812. https:// doi.org/10.1016/j.ocecoaman.2019.05.014.

Carvache-Franco, M., Segarra-Oña, M., \& Carrascosa-López, C. (2019b). Segmentation by Motivation in Ecotourism: Application to Protected Areas in Guayas, Ecuador. Sustainability, 11(1), 240. https://doi.org/10.3390/su11010240.

Castaño, J. M., Moreno, A., García, S., \& Crego, A. (2003). A psychosocial approach to tourism motivation variables involved in the choice of Madrid as a destination. Estudios Turísticos, 158, 5-41.

Cheng, A., Gursoy, D. \& Del Chiappa, G. (2016). The influence of materialism on ecotourism attitudes and behaviors. Journal of Travel Research, 55(2), 176-189. https://doi.org/10.1177\%2Fo047287514541005.

Chikuta, O., du Plessis, L., \& Saayman, M. (2017). Nature-based travel motivations for people with disabilities. African Journal of Hospitality, Tourism and Leisure, 6(1), 1-16.

Crompton, J. L. (1979). Motivations for pleasure vacation. Annals of tourism research, 6(4), 408-424. https:// doi.org/10.1016/0160-7383(79)90004-5.

Dann, G. M. (1981). Tourist motivation an appraisal. Annals of tourism research, 8(2), 187-219. https:// doi.org/10.1016/0160-7383(81)90082-7.

Das, M., \& Chatterjee, B. (2015). Ecotourism: A panacea or a predicament? Tourism Management Perspectives, 14, 3-16. https://doi.org/10.1016/j.tmp.2015.01.002.

Etzel, M. J., \& Woodside, A. G. (1982). Segmenting vacation markets: The case of the distant and near-home travelers. Journal of Travel Research, 2O(4), 10-14. https://doi.org/10.1177\%2Fo04728758202000403.

Fodness, D. (1994). Measuring tourist motivation. Annals of tourism research, 21(3), 555-581. https://doi.org/ 10.1016/0160-7383(94)90120-1.

Formica, S., \& Uysal, M. (1998). Market segmentation of an international cultural-historical event in Italy. Journal of travel research, 36(4), 16-24. https://doi.org/10.1177\%2Fo04728759803600402.

Galley, G., \& Clifton, J. (2004). The motivational and demographic characteristics of research ecotourists: Operation Wallacea volunteers in Southeast Sulawesi, Indonesia. Journal of Ecotourism, 3(1), 69-82. https://doi.org/10.1080/14724040408668150.

Holden, A., \& Sparrowhawk, J. (2002). Understanding the motivations of ecotourists: the case of trekkers in Annapurna, Nepal. International Journal of Tourism Research, 4(6), 435-446. https://doi.org/10.1002/jtr.402.

Huang, S., \& Hsu, C. H. C. (2009). Effects of travel motivation, past experience, perceived constraint, and attitude on revisit intention. Journal of Travel Research, 48(1), 29-44. https://doi.org/10.1177\%2Fo047287508328793.

Hultman, M., Kazeminia, A., \& Ghasemi, V. (2015). Intention to visit and willingness to pay premium for ecotourism: The impact of attitude, materialism, and motivation. Journal of Business Research, 68(9), 1854-1861. https://doi.org/10.1016/j.jbusres.2015.01.013.

Jang, S. S., \& Wu, C. M. E. (2006). Seniors' travel motivation and the influential factors: An examination of Taiwanese seniors. Tourism Management, 27(2), 306-316. https://doi.org/10.1016/j.tourman.2004.11.006.

Jang, S., \& Feng, R. (2007). Temporal destination revisit intention: The effects of novelty seeking and satisfaction. Tourism Management, 28, 580-590. https://doi.org/10.1016/j.tourman.2006.04.024

Johns, N., \& Gyimothy, S. (2002). Market segmentation and the prediction of tourist behavior: The case of Bornholm, Denmark. Journal of Travel Research, 4O(3), 316-327. https://doi.org/10.1177\%2F0047287 502040003009 . 
Juric, B., Cornwell, T. B., \& Mather, D. (2002). Exploring the usefulness of an ecotourism interest scale. Journal of Travel Research, 4O, 259-269. https://doi.org/10.1177\%2Fo047287502040003004.

Kang, B. H., Cho, S. J., Son, J. K., \& Shin, J. H. (2012). The study on the satisfaction and image of passenger at section seven, in Ollegil. Korean Society of Rural Planning, 18(3), 13-24. https://doi.org/10.7851/ ksrp.2012.18.3.013.

Kastenholz, E., Davis, D., \& Paul, G. (1999). Segmenting tourism in rural areas: the case of North and Central Portugal. Journal of Travel Research, 37(4), 353-363. https://doi.org/10.1177\%2Fo04728759903700405.

Kim, S. S., Crompton, J. L., \& Botha, C. (2000). Responding to competition: A strategy for sun/lost city, South Africa. Tourism Management, 21(1), 33-41. https://doi.org/10.1016/So261-5177 (99)00094-1.

Kozak, M. (2002). Comparative analysis of tourist motivations by nationality and destinations. Tourism Management, 23(3), 221-232. https://doi.org/10.1016/So261-5177(01)ooo9o-5.

Kwan, P., Eagles, P. F., \& Gebhardt, A. (2008). A comparison of ecolodge patrons' characteristics and motivations based on price levels: A case study of Belize. Journal of Sustainable Tourism, 16(6), 698718. https://doi.org/10.1080/09669580802397129.

Lau, A. L., \& McKercher, B. (2004). Exploration versus acquisition: A comparison of first-time and repeat visitors. Journal of Travel Research, 42(3), 279-285. https://doi.org/10.1177\%2F0047287503257502.

Lee, S., Lee, S., \& Lee, G. (2014). Ecotourists' motivation and revisit intention: A case study of restored ecological parks in South Korea. Asia Pacific Journal of Tourism Research, 19(11), 1327-1344. https://doi.org/10.1080/10941665.2013.852117.

Lounsbury, J. W., \& L. L. Hoopes (1985). An Investigation of Factors Associated with Vacation Satisfaction. Journal of Leisure Research, 17 (1): 1-13. https://doi.org/10.1080/00222216.1985.11969610.

Luo, Y., \& Deng, J. (2008). The New Environmental Paradigm and nature-based tourism motivation. Journal of Travel Research, 46(4), 392-402. https://doi.org/10.1177\%2Fo047287507308331.

McGehee, N. G., \& Kim, K. (2004). Motivation for agri-tourism entrepreneurship. Journal of travel research, 43(2), 161-170. https://doi.org/10.1177\%2Fo047287504268245.

Meng, F., Tepanon, Y., \& Uysal, M. (2008). Measuring tourist satisfaction by attribute and motivation: The case of a nature-based resort. Journal of Vacation Marketing, 14(1), 41-56. https://doi.org/10.1177\%2 F1356766707084218.

Nickerson, N. P., Jorgenson, J., \& Boley, B. B. (2016). Are sustainable tourists a higher spending market?. Tourism Management, 54, 170-177. https://doi.org/10.1016/j.tourman.2015.11.009.

Page, S. J., \& Dowling, R. K. (2002). Themes in tourism: ecotourism. Edinburgh Gate: Prentice-Hall.

Panin, B., \& Mbrica, A. (2014). Potentials of ecotourism as a rural development tool on the base of motivation factors in Serbia. Sustainable agriculture and rural development in terms of the Republic of Serbia strategic goals realization within the Danube region. Rural development and (un) limited resources, 597.

Pearce, P. L. (2013). The social psychology of tourist behaviour: International series in experimental social psychology (Vol. 3). Elsevier.

Rittichainuwat, B. N., Qu, H., \& Mongkhonvanit, C. (2008). Understanding the motivation of travelers on repeat visits to Thailand. Journal of Vacation Marketing, 14(1), 5-21. https://doi.org/10.1177\%2F1356766707084216.

Shoemaker, S., \& Lewis, R. C. (1999). Customer loyalty: The future of hospitality marketing. International Journal of Hospitality Management, 18, 345-370. https://doi.org/10.1016/So278-4319 (99)00042-0.

Tao, T. C., \& Wall, G. (2009). Tourism as a sustainable livelihood strategy. Tourism Management, 30 (1), $90-98$. https://doi.org/10.1016/j.tourman.2008.03.009.

Weaver, D. B., \& Lawton, L. J. (2002). Overnight ecotourist market segmentation in the Gold Coast hinterland of Australia. Journal of Travel Research, 4O(3), 270-280. https://doi.org/10.1177\%2Fo04728750204000305.

Woodside, A. G., \& Jacobs, L. W. (1985). Step Two in Benefit Segmentation: Learning the Benefits Realized by Major Travel Markets. Journal of Travel Research, 24(1), 7-13. https://doi.org/10.1177\%2Fo04728758502400102.

Wurzinger, S., \& Johansson, M. (2006). Environmental concern and knowledge of ecotourism among three groups of Swedish tourists. Journal of Travel Research, 45(2), 217-226. https://doi.org/10.1177\%2 Fo047287506291602.

Yolal, M., Rus, R. V., Cosma, S., \& Gursoy, D. (2015, July). A pilot study on spectators' motivations and their socio-economic perceptions of a film festival. In Journal of Convention \& Event Tourism (Vol. 16, No. 3, pp. 253-271). Routledge. https://doi.org/10.1080/15470148.2015.1043610.

Yoon, Y., \& Uysal, M. (2005). An examination of the effects of motivation and satisfaction on destination loyalty: a structural model. Tourism Management, 26(1), 45-56. https://doi.org/10.1016/j.tourman.2003.08.016.

Zeppel, H. (2008). Indigenous ecotourism: Sustainable development and management. Wallingford: CABI.

*** Costarrican Institute of Tourism (2017) Retrieved from: https://www.ict.go.cr/es/documentosinstitucionales/estad\%C3\%ADsticas/cifras-tur\%C3\%ADsticas/visita-a-las-\%C3\%A1reas-silvestres-protegidas -sinac/1397-2017-2/file.html.

Submitted:

22.07.2019
Revised:

03.12.2019
Accepted and published online 06.12.2019 